\title{
A RETROSPECTIVE CASE-SERIES ON THE USE OF S53P4 BIOACTIVE GLASS FOR THE ADJUNCTIVE TREATMENT OF SEPTIC DIAPHYSEAL NON-UNION
}

\author{
SÉRIE DE CASOS RETROSPECTIVO SOBRE O USO DO VIDRO BIOATIVO \\ S53P4 COMO ADJUVANTE NO TRATAMENTO DE PSEUDOARTROSES \\ INFECTADAS DA DIÁFISE DOS OSSOS LONGOS
}

\author{
Guilherme Pelosini Gaiarsa ${ }^{1}$, Paulo Roberto dos Reis ${ }^{1}$, Kodi Edson Kojima ${ }^{1}$, Jorge Santos Silva ${ }^{1}$, \\ ANA LUCIA LEI MUNHOZ LIMA ${ }^{1}$
}

1. Universidade de São Paulo, Hospital das Clínicas - HCFMUSP, Faculdade de Medicina, Instituto de Ortopedia e Traumatologia, Reconstruction and Lengthening Group, São Paulo, SP, Brazil.

\section{ABSTRACT}

Objective: Non-union and persistence of infection at a fracture site for long periods are always described as a challenge to orthopedists, especially in cases of severe compound fractures with comminution and segmental bone loss. This is a case series of septic non-unions, using S53P4 bioactive glass for adjunctive treatment, using internal syntheses or external fixators. The objective is to retrospectively evaluate the results of the use of S53P4 bioglass for the adjunctive treatment of septic non-unions. Methods: We reviewed 18 patients with septic non-unions. The patients were preoperatively classified using the Non-union Scoring System (NUSS) and union outcomes were assessed by the modified radiographic union scale in tibial (RUST) fractures. Of the 18 patients treated, six underwent internal osteosynthesis and 12 were treated with external fixators in combination with bioactive glass grafting. Results: The patients had a mean NUSS score of 56.6 (standard deviation of 7.6) and fracture union was achieved according to the RUST score in 17 of 18 cases (94.4\%), with a mean value of 10.2 (standard deviation of 1.0). One patient was lost to follow-up. Reevaluation using the modified RUST score was 12.3 (SD = 1.0), maintaining union of $17 / 18$. Conclusion: The fracture union rate was high, according to the literature, as was control of infection. Level of Evidence IV, Case series.

Keywords: Bone Diseases, Infectious. Fracture Healing. Bone Substitutes. Fractures, Ununited. Fracture Fixation. Osteomyelitis.

\section{RESUMO}

Objetivo: A não união e a persistência de infecção no local de uma fratura por períodos prolongados são sempre descritas como desafios para os ortopedistas, especialmente em casos de fraturas expostas graves, com cominuição e perdas de segmentos ósseos. Esta é uma série de casos de não consolidações infectadas, utilizando o vidro bioativo S53P4 como adjuvante no tratamento, utilizando-se sínteses internas ou fixadores externos. O objetivo é avaliar retrospectivamente os resultados do uso do biovidro S53P4 como adjuvante no tratamento de não uniões infectadas. Métodos: Foram revistos 18 pacientes com não consolidações infectadas. Os pacientes foram classificados antes da cirurgia pelo Non-Union Severity Score (NUSS), e os resultados quanto à consolidação foram avaliados pelo escore de RUST modificado (escala radiográfica de consolidação da tíbia). Dos 18 pacientes tratados, seis foram submetidos à osteossíntese interna e 12 foram tratados com fixadores externos, associados à enxertia com vidro bioativo. Resultados: Os pacientes tinham resultado NUSS médio de 56,6 (desvio padrão de 7,6) e a consolidação foi obtida segundo o escore de RUST em 17 de 18 casos (94,4\%), com valor médio de 10,2 (desvio padrão de 1.0). Um paciente abandonou o seguimento. A reavaliação pelo escore de RUST modificado foi de 12,3 (PF=1,0), mantendo a consolidação de 17/18. Conclusão: 0 índice de consolidação foi elevado, segundo a literatura, bem como controle infeccioso. Nível de evidência IV, série de casos.

Descritores: Doenças Ósseas Infecciosas. Consolidação da Fratura. Substitutos Ósseos. Fraturas não Consolidadas. Fixação de Fratura. Osteomielite.

Citation: Gaiarsa GP, Reis PR, Kojima KE, Silva JS, Lima ALLM. A retrospective case-series on the use of s53p4 bioactive glass for the adjunctive treatment of septic diaphyseal non-union. Acta Ortop Bras. [online]. 2019;27(5):273-5. Available from URL: http://www.scielo.br/aob.

All authors declare no potential conflict of interest related to this article.

\footnotetext{
Work conducted at the Universidade de São Paulo, Hospital das Clínicas HCFMUSP, Faculdade de Medicina ,Instituto de Ortopedia e Traumatologia, Reconstruction and Lengthening Group, São Paulo, SP, Brazil.

Correspondence: Guilherme Pelosini Gaiarsa . Rua Tagipuru, 1060, ap 171, Bloco Acqua, Barra Funda, São Paulo, SP, Brazil. 01156-000.

guilherme.gaiarsa@gmail.com/guilherme.gaiarsa@hc.fm.usp.br
} 


\section{INTRODUCTION}

Although definitions vary, infected or septic nonunion is defined as a state of failure of union and persistence of infection at the fracture site for 6 to 8 months. ${ }^{1}$ Infected non-unions of long bones are mostly due to a severe open fracture with extensive comminution and segmental bone loss or after internal fixation of a comminuted closed fracture. ${ }^{2}$ Associated risk factors include exposed bone devoid of vascularized periosteal coverage, purulent discharge, positive bacterial cultures from the deep surrounding wound tissues, and necrotic bone containing empty lacunae. Septic non-unions of the long bones present a significant challenge to the orthopedic surgeon in providing optimal treatment for this condition. Soft-tissue loss with multiple sinuses, osteomyelitis, osteopenia, complex deformities with limb-length inequality, stiffness of adjacent joint, multidrug-resistant infections, and smoking all complicate treatment as well as recovery. Careful debridement of necrotic tissue, protection of the soft tissue and restoration of viable vascularity to the infected site have been the goals of the surgical procedure to adequately treat osteomyelitis and septic nonunion fractures. Unfortunately, appropriate tissue debridement can leave considerable bone defects, which might be filled by bone grafts, as adjuvant to surgical and antibiotic treatments. ${ }^{3}$ There are several limitations related to the application of autologous bone graft harvesting and its consequences to the donor site. ${ }^{4,5}$ Thus, researches on the use of bone graft substitutes has gained importance over the past. Bioactive glass [BAG] is a bone graft substitute for cavitary lesions with potential long-term inhibition on bacterial growth. ${ }^{6}$

This is a case series report on the application of bioactive glass [BAG] in the management of septic non-unions. To our knowledge, there is no previous report of BAG use for this indication in the literature. This may be an interesting area for future research on BAGs and Nonunion.

\section{MATERIALS AND METHODS}

This is a retrospective study on 18 patients clinically and radiologically diagnosed with septic nonunion of long bones and treated by surgical procedure associated with bioactive glass BAG-S53P4 BonAlive $\AA$ Granules (BonAlive $\AA$, Finland) from July 2011 to July 2015. All patients were followed-up for at least one year after surgery and the Nonunion Score System (NUSS) $)^{1,7}$ was applied for pre-surgical severity evaluation and at 12 months follow-up for treatment guide. Patients underwent surgery with soft tissue coverage, infected bone resection, and application of BAG-S53P4 as a scaffold at the nonunion site, with internal synthesis or external frame fixation. All patients were also submitted to systemic antibiotic therapy administered for 3 to 6 months after surgery, as determined by the hospital's protocol. The outcomes were assessed by digital $X$-Rays and bone healing evaluation according to the Radiographic Union Scale In Tibial fractures (RUST) score ${ }^{8,9}$ and Modified RUST score ${ }^{10,11}$ at discharge visit after being followed up for up to two years, considering patients had either removed their external fixator or were healed with no deformities, pain, or new fractures at final visit. Results are descriptive and expressed in terms of mean and standard deviations (SDs). Approved By the Cientific committee under the number IOT1303. As a retrospective study no informed consent was signed.

\section{RESULTS}

Eighteen (18) patients, 6 females (33\%) and 12 males (67\%), were surgically treated for septic nonunion and underwent resection, BAG-S53P4 application with either internal $(n=6,33 \%)$ or external frame fixation ( $n=12,67 \%$ ). Mean age at surgery date was
$33.6 \pm 12.6$ years-old, with an age range of 19 to 59 years-old. Patients had mean NUSS of $56.6 \pm 7.6$ points with a range of 44 to 74 points. The bones affected were tibia in $50 \%$ and femur in $50 \%$. From the 12 patients who used external fixators, mean time to withdrawal in month was $7.2 \pm 5.6$ with a range of 3.2 to 22.6. After two years follow-up, radiological healing was achieved in $17 / 18$ (94.4\%) with mean RUST score of $10.2 \pm 1.0$ One patient was lost to follow-up.

\section{DISCUSSION}

Vital factors are involved in bone healing, including cellular environment, growth factors, bone matrix, mechanical stability and vascularization. ${ }^{7,12}$ Based on this, multiple concomitant therapies (or so called polytherapy) have been proposed for fracture healing particularly in nonunions, ${ }^{7}$ such as surgical implantation of mesenchymal stem cells (MSCs) at the nonunion sites, growth factors applications, and use of scaffolds (osteoconductive material), all aimed at stimulating the cascade of events for ultimate bone repair. Nevertheless, adequate treatment of osteomyelitis and septic non-unions is challenging and must include careful debridement of necrotic tissue, protection of the soft tissue and restoration of viable vascularity to the infected area. However, appropriate tissue debridement can leave considerable bone defects and the present case-series autologous bone graft harvesting was not an option. Thus, bioactive glass [BAG] was used as bone graft substitute for cavitary lesions for these septic nonunion and segmental lesions.

Traditional classification systems for bone non-unions are not validated for treatment follow-ups; thus Calori et al. ${ }^{1,13}$ proposed and validated the Nonunion Score System [NUSS], aiming at comparing results of similar severity nonunion cases in order to direct treatment strategies. This classification gives points to 8 bone quality and fracture/nonunion characteristics, 1 soft tissue status, and 6 patient blood tests/associated diseases status, and gives a severity score for non-unions. The first group should have usual treatment, bone graft, decortication, nail exchange or plate augmentation, the second group should receive specialized attention, the third group, over 50 points, should receive specialized attention with the Diamond concept. All patients in the present case-series were NUSS group 3 (44 to 74 points); (over 75 points should be submitted to amputation) with nonunion lesions classified as complex and characterized by impairment of both biological and mechanic conditions for bone healing. Their treatments involved resection of the nonunion and the remaining bone defect was approached by bone filling with BAG and with either internal or external fixation. Their treatments were partly in accordance with the treatment algorithm previously proposed as principles of polytherapy, ${ }^{13}$ with application of one of the biotechnological approaches, such as cells, scaffold and growth factors. In the present case-series, patients were treated with surgical resection, internal or external fixators and, instead of the proposed biotechnological approaches, BAG was applied at the nonunion site based on its potential to act as a scaffold and angiogenesis capacity and on its proven osteo-stimulation and antibacterial properties. ${ }^{14}$ On cavitary defects is was left as a standalone bone graft, on segmental bone defects it was compressed on the bone transport during the reabsorption period. Average time for radiological healing was 7.2 months $(\mathrm{SD}=$ 5.6 months), with a range of 3.2 to 22.6 , with one patient lost to follow-up and another patient presenting a non-infectious late complication outside of the follow-up window. Our radiological healing was comparable with radiological healing found in NUSS group 3 patients previously described $(9.5 \pm 1.4$ months $){ }^{13}$ 
The present higher SD and ranges in our study were probably due to sample size of the case-series (11 versus 84$).{ }^{13}$ This case series reports successfully treated septic nonunion of fractures with BAG associated to internal or external fixation and surgical debridement. The use of RUST and Modified RUST score to evaluate consolidation is an effort to have more reliable data. RUST score evaluates each cortex on AP and Lateral view and gives 3 points, Modified RUST 4 points, 1 to no callus, 2 to callus formation, 3 to bridging callus, and 4 remodelling callus, a result over 11 points is considered healed.

\section{CONCLUSION}

Patients submitted to treatment on external frames the removal of the frame with no deformation and no refracture in a one year period is a strong evidence of consolidation. The 17 patients considered healed had over 11 points on modified RUST score, considered healed by the score. Further clinical studies are required to validate BAG effectiveness for non-union treatment, as the growing evidence of BAGs effectiveness on infection control was found by our data too.

AUTHORS' CONTRIBUTIONS: Each author made significant individual contributions to this manuscript. GPG (0000-0003-1481-3048)*: Surgical treatment and review of medical records. PRR (0000-0001-9126-4359)*: Surgical treatment and clinical follow-up. KEK (0000-0002-3700-2718)*: Review of manuscripts and classification. JSS (0000-0001-8901-3120)*: Review of manuscripts. ALLML (0000-0002-2396-9880*: Clinical follow-up of infection and pertinent literature review. *ORCID (Open Researcher and Contributor ID).

\section{REFERENCES}

1. Calori GM, Phillips M, Jeetle S, Tagliabue L, Giannoudis PV. Classification of non-union: Need for a new scoring system? Injury. 2008;39(Suppl 2):59-63.

2. Wiese A, Pape HC. Bone defects caused by high-energy injuries, bone loss, infected nonunions, and nonunions. Orthop Clin North Am. 2010;41(1):1-4.

3. Fang RC, Galiano RD. Adjunctive therapies in the treatment of osteomyelitis. Semin. Plast Surg. 2009;23(2):141-7.

4. Dimitriou R, Mataliotakis GI, Angoules AG, Kanakaris NK, Giannoudis PV Complications following autologous bone graft harvesting from the iliac crest and using the RIA: A systematic review. Injury. 2011; 42(Suppl 2):S3-15.

5. Giori NJ, Beaupre GS. Femoral fracture after harvesting of autologous bone graft using a reamer/irrigator/aspirator. J Orthop Trauma. 2011; 25(2): e12-4.

6. Romanò CL, Logoluso N, Meani E, Romanò D, De Vecchi E, Vassena C, et al. A comparative study of the use of bioactive glass S53P4 and antibiotic-loaded calcium-based bone substitutes in the treatment of chronic osteomyelitis: A retrospective comparative study. Bone Joint J. 2014;96-B(6):845-50.

7. Calori GM, Giannoudis PV. Enhancement of fracture healing with the diamond concept: The role of the biological chamber. Injury. 2011;42(11): 1191-3.

8. Whelan DB, Bhandari M, Stephen D, Kreder H, McKee MD, Zdero R, et al. Development of the radiographic union score for tibial fractures for the assessment of tibial fracture healing after intramedullary fixation. J Trauma. 2010; 68(3):629-32.
9. Kooistra BW, Dijkman BG, Busse JW, Sprague S, Schemitsch EH, Bhandari M. The radiographic union scale in tibial fractures: reliability and validity. J Orthop Trauma. 2010; 24(Suppl 1):S81-6.

10. Litrenta J, Tornetta P 3rd, Ricci W, Sanders RW, O'Toole RV, Nascone JW et al. In Vivo Correlation of Radiographic Scoring (Radiographic Union Scale for Tibia Fractures) and Biomechanical Data in a Sheep Osteotomy Model. J Orthop Trauma. 2017; 31(3):127-30.

11. Litrenta J, Tornetta P 3rd, Mehta S, Jones C, O'Toole RV, Bhandari M, et al. Determination of Radiographic Healing: An Assessment of Consistency Using RUST and Modified RUST in Metadiaphyseal Fractures. J Orthop Trauma. 2015;29(11):516-20.

12. Calori GM, Mazza E, Colombo M, Ripamonti C, Tagliabue L. Treatment of long bone non-unions with polytherapy: Indications and clinical results. Injury. 2011;42(6):587-90.

13. Calori GM, Colombo M, Mazza EL, Mazzola S, Malagoli E, Marelli N, et al. Validation of the Non-Union Scoring System in 300 long bone non-unions. Injury. 2014;45(Suppl 6): S93-7.

14. Van Gestel NAP, Geurts J, Hulsen DJ, van Rietbergen B, Hofmann S, Arts JJ. Clinical Applications of S53P4 Bioactive Glass in Bone Healing and Osteomyelitic Treatment: A Literature Review. Biomed Res Int. 2015;2015:684826. 